\title{
Evaluasi Kinerja Badan Pendapatan Daerah Kota Denpasar Dalam Pemungutan Pajak Bumi Dan Bangunan Perdesaan Perkotaan
}

\author{
IGA Anastasia Sukma Putri ${ }^{1}$ \\ Naniek Noviari ${ }^{2}$ \\ ${ }^{1,2}$ Fakultas Ekonomi dan Bisnis Universitas Udayana (Unud), Bali, Indonesia \\ e-mail:putrianastasiasukma@gmail.com
}

\begin{abstract}
ABSTRAK
Tujuan penelitian ini adalah untuk mengetahui kinerja Badan Pendapatan Daerah Kota Denpasar dalam pemungutan Pajak Bumi dan Bangunan Perdesaan dan Perkotaan. Penelitian ini menggunakan data sekunder dengan analisis data yang digunakan dalam penelitian ini adalah analisis deskriptif komparatif terkait dengan value for money. Berdasarkan hasil analisis dapat diketahui bahwa kinerja Badan Pendapatan Daerah Kota Denpasar dari aspek ekonomi tergolong dalam kategori cukup ekonomis dengan memperoleh rata-rata rasio ekonomi sebesar $82 \%$, dari aspek efisien tergolong dalam kategori sangat efisien dengan memperoleh rata-rata rasio efisiensi sebesar 2,82\%, dan dari aspek efektivitas tergolong dalam kategori sangat efektif dengan memperoleh rata-rata rasio efektivitas sebesar 105\%. Upaya-upaya yang dilakukan Badan Pendapatan Daerah Kota Denpasar untuk meningkatkan pendapatan Pajak Bumi dan Bangunan Perdesaan dan Perkotaan adalah dengan cara intensifikasi dan ekstensifikasi.
\end{abstract}

Kata kunci: Kinerja, pajak bumi, value for money

\begin{abstract}
The purpose of this study was to determine the performance of the Denpasar City Revenue Agency in collecting Rural and Urban Land and Building Taxes. This study uses secondary data with data analysis used in this study is a comparative descriptive analysis related to value for money. Based on the results of the analysis, it can be seen that the performance of the Denpasar City Revenue Agency from the economic aspect is categorized as quite economical by obtaining an average economic ratio of $82 \%$, from the efficient aspect classified as very efficient by obtaining an average efficiency ratio of $2.82 \%$, and from the aspect of effectiveness classified as very effective category by obtaining an average effectiveness ratio of 105\%. The efforts made by the Denpasar City Revenue Agency to increase Rural and Urban Land and Building Taxes revenues are intensifying and extending.

Keywords: Performance, land tax, value for money
\end{abstract}

\section{PENDAHULUAN}

Kinerja instansi pemerintah kini menjadi sorotan dengan semakin tingginya kesadaran masyarakat terhadap penyelenggaran administrasi publik (Mardiasmo, 2009). Masyarakat sering menilai bahwa organisasi sektor publik merupakan sarang pemborosan, inefisiensi, dan institusi yang merugi (Purwiyanti, 2017). Masyarakat yang semakin kritis dan cerdas juga menuntut adanya transparansi 
IGA Anastasia Sukma Putri dan Naniek Noviari. Evaluasi ...

dan akuntabilitas publik oleh lembaga-lembaga organisasi sektor publik (Suryantari dan Ulupui 2016). Transparansi dan akuntabilitas yang baik dapat dicapai dengan cara melakukan pengukuran kinerja di organisasi sektor publik tersebut.

Pengukuran kinerja adalah bagian yang paling dasar dari setiap organisasi, baik itu dijalankan oleh sektor swasta maupun sektor publik (Laksmi, 2014). Pengukuran kinerja pada dasarnya merupakan perluasan dari audit keuangan dalam hal tujuan dan prosedurnya (Sangmi, 2010). Audit kinerja memfokuskan pemeriksaan pada tindakan-tindakan dan kejadian ekonomi yang menggambarkan kinerja entitas atau fungsi audit (Kadafi 2014). Kegiatan perencanaan, pengendalian biaya dan kegiatan serta evaluasi dan pengendalian tetap dijalankan di organisasi sektor pubik seperti halnya di sektor swasta (Purnomo, 2015). Organisasi sektor publik merupakan organisasi yang berorientasi pada kepentingan publik, oleh karena itu organisasi ini biasanya tidak berorientasi pada laba sebagai tujuan utamanya (Franzoni 2013). Organisasi sektor publik disini dapat berupa badan pemerintah, badan usaha milik negara, dan berbagai organisasi sektor publik lainnya (Dimitri 2013).

Pengukuran kinerja dalam organisasi sektor publik sangat diperlukan untuk menilai akuntabsilitas organisasi dalam menghasilkan pelayanan publik yang lebih baik dan tepat sasaran (Koufteros et al, 2014). Pengukuran kinerja organisasi sektor publik dilakukan untuk memenuhi 3 (tiga) tujuan. Pertama, untuk membantu memperbaiki kinerja pemerintah. Kedua, untuk pengalokasian sumber daya dan pembuatan keputusan. Ketiga, untuk mewujudkan 
pertanggungjawaban publik dan memperbaiki komunikasi kelembagaan (Mardiasmo, 2009: 121). Turunnya kinerja organisasi sektor publik dapat berdampak pada kegagalan dalam membangun maupun memperbaiki infrastruktur yang ada (Watermeyer et al, 2013).

Pada tahun 1970-an organisasi sektor publik di Inggris dipandang tidak cukup bertanggung jawab, boros, dan tidak memberikan perubahan atau perbaikan, sehingga munculah pembahasan mengenai value for money yang bertujuan untuk meningkatkan kinerja sektor publik dan mengevaluasi prosedur yang berlaku (Alwardat et al, 2015). Value for Money adalah tentang mencapai keseimbangan yang tepat antara ekonomi, efisiensi, dan efektivitas. Atau menghabiskan sedikit, menghabiskan dengan baik, dan menghabiskan dengan bijaksana. Value for Money tinggi ketika terdapat keseimbangan antara ketiga elemen, yaitu ketika biaya yang relatif rendah, produktivitas yang tinggi, dan hasil yang memuaskan telah dicapai (Barnett et al, 2010). Value for money merupakan alat manajemen publik yang signifikan yang dapat meningkatkan kinerja pemerintah daerah (Bawole et al, 2016). Value for Money perlu dan layak dibahas karena value for money berhubungan dengan sejauh mana dana yang dikeluarkan secara ekonomi dan efisien serta sejauh mana program yang dirangkai dapat efektif dalam memenuhi tujuan organisasi (Eze dan Ibrahim 2015).

Value for Money di organisasi sektor publik dapat dikatakan sebagai solusi untuk memonitoring pertumbuhan pengeluaran pemerintah, cara ini dilakukan agar dapat mengembalikan kepercayaan publik dan mengatasi tuntutan akuntabilitas publik (Jacobs, 1998). Value for money digunakan untuk meneliti 
kemampuan organisasi pemerintah dalam melaksanakan tanggung jawab dan mengontrol biaya dengan memastikan bahwa sumber daya yang dikelola atau input yang digunakan telah menggunakan biaya terendah dengan menyelenggarakan kegiatan organisasi pemerintah secara efisien (Burger and Hawkesworth 2011).

Terkadang proyek infrastruktur sering dirancang dan dipaksakan untuk lolos dalam pengujian value for money, sehingga akan menghambat dalam pengimplentasiannya (Santandrea et al, 2015).Setiap negara memiliki perangkat value for money yang berbeda-beda, namum sebelum organisasi sektor publik melakukan proyek baik itu perbaikan maupun pembuatan infrastruktur organisasi sektor publik harus melakukan serangkaian tes value for money untuk mencegah potensi kerugian dan tetap melindungi publik (Soomro et al, 2016). Value for money tidak memiliki metode pengukuran yang komprehensif, melainkan peneliti dapat membuat variasi mengenai metode pengukuran (Rosca 2013). Value for money merupakan konsep pengelolaan organisasi sektor publik yang berorientasi pada 3 (tiga) elemen utama, yaitu ekonomi, efisiensi, dan efektivitas (Rahmad 2015).

Ekonomi terkait dengan sejauh mana organisasi sektor publik dapat memperoleh sumber daya dengan harga yang relatif rendah (Marayasa, 2017). Proses kegiatan operasional dapat dikatakan efisien apabila suatu produk tertentu dapat dicapai dengan menggunakan sumber daya dan sumber dana yang serendahrendahnya. Efisiensi dapat menggambarkan perbandingan antara besarnya biaya yang dikeluarkan untuk menghasilkan pendapatan dengan besarnya realisasi 
pendapatan yang akan diterima. efektivitas dapat diukur berdasarkan berhasil atau tidaknya suatu organisasi mencapai tujuannya.Manfaat implementasi dari value for money di organisasi sektor publik antara lain dapat meningkatkan efektivitas pelayanan publik yaitu pelayanan yang diberikan tepat sasaran, alokasi belanja yang lebih berorientasi pada kepentingan publik, dan meningkatkan kesadaran akan uang publik sebagai akar pelaksanaan akuntabilitas publik (Ismail et al, 2012).

Masyarakat saat ini menuntut adanya transparansi dan akuntabilitas publik oleh lembaga-lembaga daerah termasuk Badan Pendapatan Daerah. Badan Pendapatan Daerah tergolong dalam organisasi sektor publik yang berfungsi untuk menunjang pemerintahan baik dalam perbaikan maupun pembangunan infrastruktur (Liando dkk, 2014). Saat ini pemungutan pajak daerah dilakukan oleh Badan Pendapatan Daerah Provinsi maupun Badan Pendapatan Daerah Kabupaten atau Kota.

Menurut Undang-Undang Nomor 33 Tahun 2004 tentang Perimbangan Keuangan Antara Pemerintah Pusat dan Pemerintah Daerah. Pendapatan Asli Daerah adalah pendapatan yang diperoleh Daerah yang dipungut berdasarkan Peraturan Daerah sesuai dengan peraturan perundang-undangan. Pendapatan Asli Daerah (PAD) setiap daerah berbeda-beda. Daerah yang memiliki kemajuan dibidang industri dan memiliki kekayaan alam yang melimpah cenderung memiliki PAD yang jauh lebih besar dibanding daerah lainnya, begitu juga sebaliknya.Semakin tinggi PAD maka semakin kecil ketergantungan suatu daerah terhadap pemerintah pusat maupun pemerintah daerah lainnya (Taras 2017). 
Berikut ini disajikan Tabel 1 mengenai penerimaan Pendapatan Asli Daerah (PAD) kota Denpasar.

\section{Tabel 1.}

Penerimaan Pendapatan Asli Daerah (PAD) Kota Denpasar dari Tahun 2013-2017 (dalam ribuan rupiah)

\begin{tabular}{ccc}
\hline Tahun & Target (Rp) & Realisasi (Rp) \\
\hline 2013 & 586.955 .993 & 658.974 .707 \\
2014 & 644.117 .977 & 698.739 .758 \\
2015 & 724.497 .965 & 776.214 .148 \\
2016 & 740.366 .097 & 807.042 .113 \\
2017 & 932.703 .422 & 941.739 .998 \\
\hline
\end{tabular}

Sumber: Data diolah, 2018

Pendapatan Asli Daerah dapat bersumber dari pajak daerah, retribusi daerah, hasil pengelolaan kekayaan daerah yang tidak dipisahkan, serta lain-lain PAD yang sah. Pemilihan Pajak Bumi dan Bangunan Perdesaan dan Perkotaan karena Pajak Bumi dan Bangunan Perdesaan dan Perkotaan merupakan pajak daerah yang dipungut dan dikelola oleh Badan Pendapatan Daerah Kota Denpasar.

Pemilihan Kota Denpasar sebagai tempat penelitian disebabkan oleh beberapa alasan. Pertama, Kota Denpasar merupakan ibu kota provinsi Bali dan sekaligus sebagai pusat pemerintah, pendidikan, dan perekonomian. Kedua, Kota Denpasar merupakan titik sentral berbagai kegiatan sekaligus sebagai penghubung dengan kabupaten lainnya. Ketiga, penelitian yang dilakukan di Kota Denpasar masih sedikit. Keempat, Kota Denpasar memiliki gedung Graha Sewaka Dharma yang dapat mempermudah masyarakat dalam memperoleh informasi mengenai pembayaran pajak daerah maupun informasi yang lainnya. Kelima, Kota Denpasar memiliki aplikasi pengaduan online yaitu Pro Denpasar yang berfungsi sebagai 
tempat pengaduan masyarakat secara online untuk mengadukan keluhan terkait pelayanan maupun infrastruktur yang ada di Kota Denpasar.

Berdasarkan lembaga pemungutan pajak di Indonesia dapat dibedakan menjadi 2 (dua) yaitu pajak pusat dan pajak daerah (Direktorat Jendral Pajak, 2012).Pemungutan pajak daerah dilakukan oleh Badan Pendapatan Daerah tingkat Provinsi dan Badan Pendapatan Daerah Kabupaten atau Kota.Adapun pajak daerah yang dipungut oleh Badan Pendapatan Daerah tingkat Provinsi, yaitu pajak kendaraan bermotor, bea balik nama kendaraan bermotor, pajak bahan bakar kendaraan bermotor, pajak air permukaan, dan pajak rokok. Sedangkan, pajak daerah yang dipungut oleh Badan Pendapatan Daerah Kabupaten atau Kota, yaitu pajak hotel, pajak restoran, pajak hiburan, pajak reklame, pajak penerangan jalan, pajak mineral bukan logam dan batuan, pajak parkir, pajak air tanah, pajak sarang burung walet, pajak bumi dan bangunan perdesaan dan perkotaan, serta bea perolehan hak atas tanah dan bangunan. Pemerintah Kota Denpasar melalui Badan Pendapatan Daerah Kota Denpasar hanya memungut 9 (sembilan) jenis pajak daerah dapat dilihat pada Tabel 2. 
Tabel 2.

Realisasi Penerimaan Pajak Daerah Kota Denpasar Tahun 2013-2017 (dalam ribuan rupiah)

\begin{tabular}{|c|c|c|c|c|c|}
\hline \multirow{2}{*}{ Pajak Daerah } & \multicolumn{5}{|c|}{ Tahun } \\
\hline & 2013 & 2014 & 2015 & 2016 & 2017 \\
\hline Pajak Hotel & 113.504 .495 & 118.810 .578 & 133.349 .921 & 149.003 .924 & 161.589 .921 \\
\hline Pajak Restoran & 56.577 .597 & 64.957 .135 & 73.837 .361 & 86.873 .174 & 107.556 .622 \\
\hline Pajak Hiburan & 9.723 .711 & 10.634 .426 & 11.664 .482 & 13.960 .864 & 18.424 .593 \\
\hline $\begin{array}{l}\text { Pajak Reklame } \\
\text { Pajak Penerangan }\end{array}$ & 9.647 .337 & 1.637 .901 & 2.037 .170 & 2.082 .920 & 2.523 .717 \\
\hline Jalan & 55.731 .803 & 66.225 .005 & 76.117 .800 & 83.551 .087 & 87.071 .633 \\
\hline Pajak Air Tanah & 8.004 .804 & 8.416 .599 & 9.570 .019 & 9.250 .786 & 10.536 .066 \\
\hline $\begin{array}{l}\text { Pajak Bumi dan } \\
\text { Bangunan Perdesaan } \\
\text { dan Perkotaan }\end{array}$ & 92.884 .127 & 98.675 .183 & 107.696 .759 & 113.509 .517 & 102.945 .770 \\
\hline ВРНТВ & 158.907 .687 & 141.225 .825 & 135.089 .430 & 122.963 .525 & 207.393 .826 \\
\hline Pajak Parkir & - & - & - & - & 3.299 .083 \\
\hline
\end{tabular}

Sumber: Badan Pendapatan Daerah Kota Denpasar, 2018

Pemilihan Pajak Bumi dan Bangunan Perdesaan dan Perkotaan dalam penelitian ini karena terdapat beberapa alasan. Pertama, karena Pajak Bumi dan Bangunan Perdesaan dan Perkotaan merupakan pajak daerah yang dipungut oleh Badan Pendapatan Daerah Kota Denpasar. Kedua, di tahun 2016 Pajak Bumi dan Bangunan Perdesaan dan Perkotaan merupakan pajak yang masih menjadi andalan dalam pendapatan Kota Denpasar (Wibisono, 2016). Ketiga, karena sistem pemungutan pajak untuk Pajak Bumi dan Bangunan Perdesaan dan Perkotaan adalah official assessment system. Keempat, karena Peraturan Daerah yang mengatur mengenai NJOP Pajak Bumi dan Bangunan Perdesaan dan Perkotaan di Kota Denpasar belum mengalami perbaruan dimana seharusnya dilakukan dalam jangka waktu 3 (tiga) tahun. Kelima, karena hanya Pajak Bumi dan Bangunan Perdesaan dan Perkotaan yang mengalami penurunan realisasi 
penerimaan di tahun 2017. Keenam, karena wajib pajak untuk Pajak Bumi dan Bangunan Perdesaan dan Perkotaan bertambah setiap tahunnya. Berikut ini disajikan Tabel 3 mengenai jumlah wajib Pajak Bumi dan Bangunan Perdesaan dan Perkotaan di Kota Denpasar.

Tabel 3.

Jumlah Wajib Pajak Bumi dan Bangunan Perdesaan dan Perkotaan Kota Denpasar tahun 2013-2017

\begin{tabular}{cc}
\hline Tahun & Jumlah Wajib Pajak Pumi dan Bangunan Perdesaan dan Perkotaan \\
\hline 2013 & 132.491 \\
2014 & 132.743 \\
2015 & 133.858 \\
2016 & 181.351 \\
2017 & 182.691 \\
\hline Sumber:Data diolah, 2018
\end{tabular}

Penelitian ini dilakukan di Badan Pendapatan Daerah Kota Denpasar karenaBadan Pendapatan Daerah Kota Denpasarmemerlukan adanya evaluasi kinerja untuk mengetahui kinerjanya dalam pemungutan pajak daerah, khususnya Pajak Bumi dan Bangunan Perdesaan dan Perkotaan serta untuk meningkatkan kinerjanya di masa yang akan datang. Penelitian ini akan mengevaluasi kinerja Badan Pendapatan Daerah Kota Denpasar dengan menggunakan konsep value for money yang terdiri dari 3 (tiga) aspek, yaitu ekonomi, efisiensi, dan efektivitas. Penelitian ini dilakukan untuk mengevaluasi kinerja Badan Pendapatan Daerah Kota Denpasar dengan menggunakan data yang terdapat di Laporan Kinerja Instansi Pemerintah dan Laporan Realisasi Penerimaan Pendapatan Asli Daerah Kota Denpasar. 


\section{METODE PENELITIAN}

Penelitian ini dilakukan di Badan Pendapatan Daerah Kota Denpasar yang beralamat di Jl. Letda Tantular No. 12 Denpasar. Badan Pendapatan Daerah Kota Denpasar dipilih sebagai lokasi penelitian karena untuk Pajak Bumi dan Bangunan Perdesaan dan Perkotaan di Kota Denpasar dipungut dan dikelola oleh Badan Pendapatan Daerah Kota Denpasar.

Objek penelitian ini yaitu kinerja Badan Pendapatan Daerah Kota Denpasar dalam pemungutan Pajak Bumi dan Bangunan Perdesaan dan Perkotaan. Objek penelitian ini dipilih karena dirasakan perlu adanya evaluasi kinerja di Badan Pendapatan Daerah Kota Denpasar khususnya dalam Pajak Bumi dan Bangunan Perdesaan dan Perkotaan. Hal ini dikarenakan adanya penurunan realisasi penerimaan di tahun 2017 sehingga penulis ingin mengetahui apakah kinerja Badan Pendapatan Daerah Kota Denpasar selama 5 (lima) tahun terakhir sudah ekonomis, efisiensi, dan efektif.

Pengukuran ekonomi dalam penelitian ini dilalukan dengan perhitungan sebagai berikut.

Ekonomi $=\frac{\text { Realisasi biaya untuk memungut } \mathrm{PBB}}{\text { Anggaran biaya untuk memungut } \mathrm{PBB}} \times 100 \%$

Pengukuran efisiensi dalam penelitian ini dilalukan dengan perhitungan sebagai berikut.

Efisiensi $=\frac{\text { Realisasi biaya untuk memungut PBB }}{\text { Realisasi penerimaan PBB }} \times 100 \%$

Pengukuran efektivitas dalam penelitian ini dilalukan dengan perhitungan sebagai berikut. 
Efektivitas $=\frac{\text { Realisasi penerimaan PBB }}{\text { Target penerimaan PBB }} \times 100 \%$

Data yang digunakan dalam penelitian ini adalah data kuantitatif dan data kualitatif. Data kuantitatif pada penelitian ini adalah data target dan realisasi penerimaan PAD, data target dan realisasi Pajak Bumi dan Bangunan Perdesaan dan Perkotaan di Kota Denpasar, serta anggaran biaya dan realisasi biaya yang dikeluarkan untuk memungut Pajak Bumi dan Bangunan Perdesaan dan Perkotaan. Data kualitatif dalam penelitian ini adalah gambaran umum, sejarah berdiri Badan Pendapatan Daerah Kota Denpasar, visi dan misi, serta struktur organisasi Badan Pendapatan Daerah Kota Denpasar.

Sumber data dalam penelitian ini adalah data primer dan data sekunder. Data primer dalam penelitian ini, yaitu berupa hasil wawancara yang dilakukan di Badan Pendapatan Daerah Kota Denpasar. Data sekunder dalam penelitian ini, yaitu berupa data mengenai realisasi penerimaan pajak daerah Kota Denpasar, target dan realisasi PAD Kota Denpasar, data target dan realisasi penerimaan Pajak Bumi dan Bangunan Perdesaan dan Perkotaan, anggaran biaya dan realisasi biaya yang dikeluarkan dalam memungut Pajak Bumi dan Bangunan Perdesaan dan Perkotaan, gambaran umum, visi dan misi, tugas dan fungsi Badan Pendapatan Daerah Kota Denpasar, serta struktur organisasi Badan Pendapatan Daerah Kota Denpasar.

Metode pengumpulan data yang digunakan dalam penelitian ini adalah metode dokumentasi dan wawancara. Metode dokumentasi adalah sebuah metode pengumpulan data dengan mengumpulkan seluruh dokumen-dokumen, baik dokumen tertulis maupun tidak tertulis dan kemudian melakukan analisis terhadap 
dokumen tersebut (Sugiyono, 2017). Data yang di dapat dari metode ini adalah data mengenai realisasi penerimaan PAD Kota Denpasar, target dan realisasi penerimaan Pajak Bumi dan BangunanPerdesaan dan PerkotaanKota Denpasar,serta anggaran biaya dan realisasi biaya yang dikeluarkan dalam memungut PajakBumi dan Bangunan Perdesaan dan Perkotaan. Wawancara merupakan suatu metode pengumpulan yang dilakukan dengan cara tatap muka dan tanya jawab langsung antara peneliti dan narasumber (Sugiyono, 2017). Metode pengumpulan data dengan cara wawancara dalam penelitian ini dilakukan dengan membuat daftar pertanyaan mengenai kendala, upaya, dan kegiatan peningkatan SDM yang telah dilakukan oleh Badan Pendapatan Daerah Kota yang dikonfirmasi kepada Kepala Bidang Pendaftaran, Pendataan, dan Penetapan; Kepala Sub. Bidang Pendataan dan Penilaian serta Kepala Sub. Bidang Pengelolaan Data.

Teknik analisis data yang digunakan dalam penelitian ini adalah metode analisis deskriptif komparatif. Tujuan dari penelitian deskriptif ini adalah unuk mengevaluasi kinerja Badan Pendapatan DaerahKota Denpasar dalam pemungutan Pajak Bumi dan Bangunan Perdesaan dan Perkotaan dengan menggunakan konsep value for money ditinjau dari perspektif ekonomi, efisiensi, dan efektivitas.

\section{HASIL DAN PEMBAHASAN}

Data yang diperlukan untuk mengevaluasi kinerja Badan Pendapatan Daerah Kota Denpasar dalam pemungutan Pajak Bumi dan Bangunan Perdesaan dan Perkotaan 
dengan menggunakan konsep value for money yaitu dapat dilihat pada Tabel 4 dan Tabel 5 sebagai berikut.

Tabel 4.

Anggaran dan Realisasi Biaya yang dikeluarkan untuk Memungut Pajak Bumi dan Bangunan Perdesaan dan Perkotaan 2013-2017

\begin{tabular}{|c|c|c|c|c|c|}
\hline \multirow{2}{*}{ Keterangan } & \multicolumn{5}{|c|}{ Tahun } \\
\hline & 2013 & 2014 & 2015 & 2016 & 2017 \\
\hline Anggaran (Rp) & 4.760 .455 .800 & 4.640 .840 .950 & 4.566 .666 .000 & 4.291 .936 .000 & 337.950 .500 \\
\hline Realisasi (Rp) & 4.489 .654 .788 & 4.571 .258 .662 & 4.548 .413 .483 & 101.186 .000 & 320.486 .900 \\
\hline $\begin{array}{c}\text { \% Realisasi } \\
\text { Anggaran }\end{array}$ & $94 \%$ & $99 \%$ & $100 \%$ & $24 \%$ & $95 \%$ \\
\hline
\end{tabular}

Sumber:Data diolah, 2018

Tabel 5 menyajikan data target dan realisasi penrimaan pajak bumi dan bangunan perdesaan dan perkotaan periode tahun $2013-2017$

Tabel 5.

Target dan Realisasi Penerimaan Pajak Bumi dan Bangunan Perdesaan dan Perkotaan 2013-2017

\begin{tabular}{cccccc}
\hline Keterangan & $\mathbf{2 0 1 3}$ & $\mathbf{2 0 1 4}$ & $\mathbf{2 0 1 5}$ & $\mathbf{2 0 1 6}$ & $\mathbf{2 0 1 7}$ \\
\hline Target (Rp) & 83.500 .000 .0 & 94.500 .000 .0 & 105.451 .464 .0 & 107.000 .000 .0 & 102.000 .000 .0 \\
Realisasi & 92.884 .127 .3 & 98.685 .571 .4 & 107.696 .759 .5 & 113.509 .517 .5 & 102.945 .770 .3 \\
(Rp) & 07 & 72 & 64 & 07 & 45 \\
& & & & & \\
\% Realisasi & $111 \%$ & $104 \%$ & $102 \%$ & $106 \%$ & $101 \%$ \\
Target & & & & &
\end{tabular}

Sumber: Data diolah, 2018

Pengukuran rasio ekonomi terkait dengan sejauh mana organisasi sektor publik dapat mencegah pengeluaran atau pemborosan yang tidak produktif (Mardiasmo, 2009). Suatu kinerja dapat dikatakan ekonomis apabila realisasi biaya lebih kecil daripada target anggaran. Pengukuran rasio ekonomi dalam penelitian ini menggunakan perhitungan sebagai berikut (Mahmudi, 2011): 
IGA Anastasia Sukma Putri dan Naniek Noviari. Evaluasi ...

Rasio Ekonomi $=\frac{\text { Realisasi biaya untuk memungut } \mathrm{PBB}}{\text { Anggaran biaya untuk memungut } \mathrm{PBB}} \times 100 \%$

Berikut ini adalah Tabel 6 yang menjelaskan mengenai pengukuran kinerja Badan Pendapatan Daerah Kota Denpasar dalam pemungutan Pajak Bumi dan Bangunan Perdesaan dan Perkotaan periode 2013-2017.

Tabel 6.

\begin{tabular}{ccccc}
\multicolumn{5}{c}{ Rasio Ekonomi untuk Pemungutan Pajak Bumi dan Bangunan Perdesaan } \\
dan Perkotaan
\end{tabular}

Sumber: Data diolah, 2018

Berdasarkan Tabel 6 terlihat bahwa kinerja ekonomi Badan Pendapatan

Daerah Kota Denpasar untuk pemungutan Pajak Bumi dan Bangunan Perdesaan dan Perkotaan tahun 2013-2017 mengalami fluktuasi. Fluktuasi dalam pengukuran kinerja berdasarkan aspek ekonomi disebabkan karena adanya pengeluaran realisasi biaya yang berbeda-beda setiap tahunnya. Dapat dilihat pada tabel, di tahun 2013 rasio ekonomi untuk pemungutan Pajak Bumi dan Bangunan Perdesaan dan Perkotaan yaitu sebesar 94\% dan termasuk dalam kriteria kurang ekonomis. Pada tahun 2014 mengalami peningkatan rasio ekonomi jika dibandingkan dengan tahun 2013, dapat dilihat dari persentase rasio ekonomi di tahun 2014 yaitu sebesar 99\% dan berada dalam kriteria kurang ekonomis. Ditahun 2015 kembali mengalami peningkatan yaitu menjadi 100\% dengan kriteria kurang ekonomis. Pada tahun 2016 kinerja ekonomi Badan Pendapatan Daerah Kota Denpasar mengalami penurunan yang cukup tajam dengan rasio 
ekonomi yaitu sebesar $24 \%$ dengan kriteria sangat ekonomis. Penurunan rasio ekonomi ini disebabkan oleh salah satu kegiatan pelayanan Pajak Bumi dan Bangunan Perdesaan dan Perkotaan yaitu kegiatan pemberian sosialisasi kepada Wajib Pajak yang tanahnya ditetapkan sebagai ruang terbuka hijau kota dan bagi tanah yang diperuntuhkan untuk pertanian telah dihapuskan oleh Pemerintah Kota Denpasar, sehingga pada tahun 2016 anggaran untuk kegiatan tersebut masih dibuat sedangkan tidak ada realisasi biaya yang dikeluarkan. Di tahun 2017 persentase rasio ekonomi mengalami peningkatan yaitu menjadi 95\% dengan kriteria kurang ekonomis. Kenaikan persentase rasio ekonomi pada tahun 2017 disebabkan karena anggaran untuk kegiatan pemberian sosialisasi kepada Wajib Pajak telah dihapuskan oleh Pemerintah Kota Denpasar. Rata-rata untuk rasio ekonomi di Badan Pendapatan Daerah Kota Denpasar adalah 82\% dan termasuk dalam kriteria cukup ekonomis dapat dilihat pada Tabel 6.

Kinerja pemerintah daerah dapat dikategorikan efisien dalam melakukan pemungutan pendapatan apabila rasio yang dicapai di bawah 60\% (Yeni, 2013). Semakin kecil rasio efisiensi maka kinerja pemerintah daerah semakin baik. Suatu kegiatan operasional dapat dikatakan efisien apabila suatu hasil kerja tertentu dicapai dengan menggunakan sumber dana dan sumber daya yang serendahrendahnya (Mardiasmo, 2009). Apabila pengukuran rasio efisiensi disuatu unit kerja lebih besar dibandingkan dengan hasil rasio program yang sama di unit kerja lain, maka program tersebut dapat dikatakan lebih efisien (Yeni, 2013). Pengukuran rasio efisiensi dalam penelitian ini dapat menggunakan perhitungan sebagai berikut (Halim, 2008): 
IGA Anastasia Sukma Putri dan Naniek Noviari. Evaluasi ...

Rasio Efisiensi $=\frac{\text { Realisasi biaya untuk memungut PBB }}{\text { Realisasi penerimaan PBB }} \times 100 \%$

Berikut ini adalah Tabel 7 yang menjelaskan mengenai pengukuran kinerja Badan Pendapatan Daerah Kota Denpasar dalam pemungutan Pajak Bumi dan Bangunan Perdesaan dan Perkotaan periode 2013-2017.

Tabel 7.

\begin{tabular}{ccccc}
\multicolumn{5}{c}{ Rasio Efisiensi untuk Pemungutan Pajak Bumi dan Bangunan Perdesaan } \\
dan Perkotaan \\
Tahun & Realisasi Biaya (Rp) & Realisasi Penerimaan (Rp) & $\begin{array}{c}\text { Rasio } \\
\text { Efisiensi } \\
(\%)\end{array}$ & Kriteria \\
& & & & \\
& $\mathrm{A} / \mathrm{B}$ x & \\
& $\mathrm{A}$ & $\mathrm{B}$ & $100 \%$ & \\
\hline 2013 & 588.611 .200 & 92.884 .127 .307 & $0,63 \%$ & Sangat efisien \\
2014 & 612.988 .900 & 98.685 .571 .472 & $0,62 \%$ & Sangat efisien \\
2015 & 127.481 .000 & 107.696 .759 .564 & $0,12 \%$ & Sangat efisien \\
2016 & 101.186 .000 & 113.509 .517 .507 & $0,09 \%$ & Sangat efisien \\
2017 & 320.486 .900 & 102.945 .770 .345 & $0,31 \%$ & Sangat efisien \\
Rata-rata & 350.150 .800 & 103.144 .349 .239 & $0,35 \%$ & Sangat efisien \\
\hline Sumber: Data diolah, 2018 & & & \\
\hline
\end{tabular}

Berdasarkan Tabel 7 diketahui bahwa rasio efisiensi untuk pemungutan Pajak Bumi dan Bangunan Perdesaan dan Perkotaan mengalami fluktuasi dari tahun 2013-2017, hal ini disebabkan karena adanya perbedaan realisasi biaya yang dikeluarkan setiap tahunnya serta adanya perbedaan realisasi penerimaan yang diterima oleh Badan Pendapatan Daerah Kota Denpasar. Rata-rata dari rasio efisiensi adalah sebesar 2,82\% dengan kriteria sangat efisien. Di tahun 2013 kinerja Badan Pendapatan Daerah Kota Denpasar telah memenuhi kriteria sangat efisien karena berada pada nilai 4,83\% dan juga karena rasionya kurang dari $60 \%$. Pada tahun 2014 persentase rasio efisiensinya sebesar 4,63\% dan termasuk dalam kriteria sangat efisien. Di tahun 2015 kinerja Badan Pendapatan Daerah Kota Denpasar dari segi efisiensi telah memenuhi kriteria sangat efisien karena memiliki rasio sebesar 4,22\%. Pada tahun 2016 kriteria efisiensi juga berada di 
tingkat sangat efisien yaitu sebesar $0,09 \%$. Penurunan rasio efisiensi yang terjadi di tahun 2016 disebabkan oleh realisasi biaya yang dikeluarkan sangat rendah sedangkan realisasi penerimaannya cukup besar, hal ini menandakan bahwa kinerja Badan Pendapatan Daerah Kota Denpasar semakin baik. Rasio efisiensi di tahun 2017 yaitu sebesar $0,31 \%$ dengan kriteria sangat efisien, walaupun adanya kenaikan dalam rasio efisiensi di tahun 2017 hal ini tidak mempengaruhi kriteria dalam pengukuran kinerja berdasarkan aspek efisiensi. Peningkatan rasio efisiensi di tahun 2017 disebabkan karena adanya peningkatan realisasi biaya yang dikeluarkan untuk memungut Pajak Bumi dan Bangunan Perdesaan dan Perkotaan.

Efektivitas merupakan perbandingan antara outcome dengan output. Semakin tinggi nilai rasio efektivitas, maka suatu kegiatan atau program tersebut dapat dikatakan semakin efektif. Dalam mencapai tujuan biasanya organisasi sektor publik tidak memperhatikan biaya yang dikeluarkan. Pengukuran rasio efektivitas dalam penelitian ini menggunakan perhitungan sebagai berikut (Halim, 2008):

Rasio Efektivitas $=\frac{\text { Realisasi Penerimaan PBB }}{\text { Target Penerimaan PBB }} \times 100 \%$

Berikut ini adalah Tabel 8 yang menjelaskan mengenai pengukuran kinerja Badan Pendapatan Daerah Kota Denpasar dalam pemungutan Pajak Bumi dan Bangunan Perdesaan dan Perkotaan periode 2013-2017. 
Tabel 8.

\begin{tabular}{|c|c|c|c|c|}
\hline \multicolumn{5}{|c|}{$\begin{array}{c}\text { Rasio Efektivitas untuk Pemungutan Pajak Bumi dan Bangunan Perdesaan } \\
\text { dan Perkotaan }\end{array}$} \\
\hline \multirow[t]{2}{*}{ Tahun } & $\begin{array}{l}\text { Target Penerimaan } \\
\quad(\mathrm{Rp})\end{array}$ & Realisasi Penerimaan (Rp) & $\begin{array}{c}\text { Rasio } \\
\text { Efektivitas } \\
(\%)\end{array}$ & Kriteria \\
\hline & A & B & $\begin{array}{l}\mathrm{B} / \mathrm{A} \mathrm{x} \\
100 \%\end{array}$ & \\
\hline 2013 & 83.500 .000 .000 & 92.884 .127 .307 & $111 \%$ & Sangat efektif \\
\hline 2014 & 94.500 .000 .000 & 98.685 .571 .472 & $104 \%$ & Sangat efektif \\
\hline 2015 & 105.451 .464 .000 & 107.696 .759 .564 & $102 \%$ & Sangat efektif \\
\hline 2016 & 107.000 .000 .000 & 113.509 .517 .507 & $106 \%$ & Sangat efektif \\
\hline 2017 & 102.000 .000 .000 & 102.945 .770 .345 & $101 \%$ & Sangat efektif \\
\hline Rata-rata & 98.490 .292 .800 & 103.144 .349 .239 & $105 \%$ & Sangat efektif \\
\hline
\end{tabular}

Berdasarkan Tabel 8 diketahui bahwa rasio efektivitas untuk pemungutan

Pajak Bumi dan Bangunan Perdesaan dan Perkotaaan mengalami fluktuasi. Penyebab rasio efektivitas berfluktuasi karena adanya perbedaan target dan realisasi penerimaan setiap tahunnya serta adanya selisih antara realisasi dan target penerimaan, jika semakin tinggi selisih antara realisasi dan target penerimaan maka semakin tinggi pula rasio efektivitasnya. Rata-rata rasio efektivitas adalah sebesar $105 \%$ dan termasuk dalam kriteria sangat efektif. Berdasarkan tabel di atas diketahui bahwa di tahun 2013 kinerja Badan Pendapatan Daerah Kota Denpasar berada pada kriteria sangat efektif dapat dilihat dari rasio yang dihasilkan yaitu sebesar $111 \%$ yang berada di atas $100 \%$. Kemudian pada tahun 2014 persentase efektivitasnya mengalami penurunan sebesar $7 \%$, namun persentase efektivitasnya tetap berada di atas $100 \%$ yaitu sebesar 104\% dengan kriteria sangat efektif. Di tahun 2015 kembali terjadi penurunan rasio efektivitas sebesar $2 \%$ tetapi efektivitasnya masih berada di atas $100 \%$ yaitu sebesar 102\% dengan kriteria sangat efektif. Pada tahun 2016 Badan 
Pendapatan Daerah Kota Denpasar berupaya untuk meningkatkan kinerjanya, terbukti pada tahun 2016 realisasi penerimaan dan persentase efektivitasnya mengalami peningkatan yaitu menjadi 106\%. Namun, di tahun 2017 persentase efektivitasnya kembali mengalami penurunan sebesar 5\% sehingga besar persentase rasio efektivitasnya menjadi $101 \%$ dan masih tetap berada pada kriteria sangat efektif. Penurunan rasio ini disebabkan karena adanya penurunan target dan realisasi penerimaan di tahun 2017 yang menyebabkan penurunan rasio efektivitas.

Wawancara merupakan suatu metode pengumpulan data yang dilakukan dengan cara tatap muka dan tanya jawab langsung antara peneliti dengan narasumber (Sugiyono, 2017). Wawancara dalam penelitian ini dilakukan di Badan Pendapatan Daerah Kota Denpasar dan dikonfirmasi kepada Kepala Bidang Pendaftaran, Pendataan, dan Penetapan; Kepala Sub. Bidang Pendataan dan Penilaian serta Kepala Sub. Bidang Pengelolaan Data. Wawancara ini terkait dengan kendala yang dihadapi Badan Pendapatan Daerah Kota Denpasar dalam pemungutan Pajak Bumi dan Bangunan Perdesaan dan Perkotaan, upaya yang telah dilakukan Badan Pendapatan Dearah Kota Denpasar dalam meningkatkan penerimaan pendapatan Pajak Bumi dan Bangunan Perdesaan dan Perkotaan, serta kegiatan yang dilakukan Badan Pendapatan Daerah Kota Denpasar dalam meningkatkan SDM untuk pemungutan Pajak Bumi dan Bangunan Perdesaan dan Perkotaan.

Adapun hasil wawancara yaitu, upaya yang dilakukan Badan Pendapatan Daerah Kota Denpasar dalam meningkatkan penerimaan pendapatan Pajak Bumi 
dan Bangunan Perdesaan dan Perkotaan adalah dengan melakukan intensifikasi dan ekstensifikasi melalui beberapa kegiatan yaitu seperti peningkatan infrastruktur dan sarana prasarana, peningkatan SDM melalui diklat, bimtek, dan pelatihan perpajakan, penyempurnaan regulasi-regulasi untuk Pajak Bumi dan Bangunan Perdesaan dan Perkotaan, melakukan pengembangan dan peningkatan sistem Pajak Bumi dan Bangunan Perdesaan dan Perkotaan, melakukan pendataan secara berkesinambungan, melakukan kerjasama dengan UGM, serta mengembangkan sistem pembayaran melalui PT. BPD Bali dan PT. POS. Kendala yang dihadapi Badan Pendapatan Daerah Kota Denpasar dalam pemungutan Pajak Bumi dan Bangunan Perdesaan dan Perkotaan diantaranya banyaknya alamat wajib pajak yang tidak jelas, adanya pergantian kepemilikan, dan kepala lingkungan yang kurang aktif dalam penyerahan SPPT ke warganya. Badan Pendapatan Daerah Kota Denpasar juga melakukan kegiatan dalam hal meningkatan SDM, hal ini dilakukan agar nantinya para pegawai di Badan Pendpatan Daerah Kota Denpasar dapat menjelaskan pertanyaan-pertanyaan yang dilontarkan oleh wajib pajak. Kegiatan peningkatan SDM melalui diklat, bimtek, maupun pelatihan perpajakan ini dapat diikuti oleh seluruh pegawai baik itu Kepala Sub. Bagian, Kepala Bidang, Kepala Sub Bidang, dan seluruh jajarannya.

Implikasi teoritis dari hasil penelitian ini adalah diketahuinya kinerja Badan Pendapatan Daerah Kota Denpasar dengan menggunakan konsep value for money. Diharapkan dengan diketahuinya kinerja Badan Pendapatan Daerah Kota Denpasar dengan menggunakan konsep value for money dapat meningkatkan realisasi penerimaan dari Pajak Bumi dan Bangunan Perdesaan dan Perkotaan dan 
sekaligus dapat meningkatkan pendapatan pajak daerah dan PAD di Kota Denpasar.

Implikasi praktis hasil penelitian ini adalah penelitian ini diharapkan dapat memberikan masukan untuk Badan Pendapatan Daerah Kota Denpasar dalam membuat keputusan di masa yang akan datang. Penelitian ini diharapkan juga dapat membantu masyarakat maupun pihak-pihak lain yang ingin mengetahui kinerja Badan Pendapatan Daerah Kota Denpasar dalam pemungutan Pajak Bumi dan Bangunan Perdesaan dan Perkotaan. Setelah masuknya Pajak Bumi dan Bangunan Perdesaan dan Perkotaan sebagai pajak daerah yang dikelola oleh Pemerintah Kabupaten/Kota kinerja Badan Pendapatan Daerah Kota Denpasar semakin membaik yang dapat dilihat dengan semakin meningkatnya PAD Kota Denpasar setiap tahunnya. Diharapkan dengan kinerja Badan Pendapatan Daerah Kota Denpasar yang semakin membaik dapat meningkatkan penerimaan pendapatan pajak daerah dan PAD Kota Denpasar.

\section{SIMPULAN}

Berdasarkan hasil penelitian dan pembahasan yang telah dijelaskan di atas, maka simpulan yang dapat ditarik dari penelitian ini adalah kinerja Badan Pendapatan Daerah Kota Denpasar berdasarkan konsep value for money untuk pemungutan Pajak Bumi dan Bangunan Perdesaan dan Perkotaan periode 2013-2017 jika ditinjau dari analisis rasio ekonomi termasuk dalam kriteria cukup ekonomis karena menunjukkan rata-rata nilai rasio di bawah $100 \%$ yaitu sebesar $82 \%$. Berdasarkan analisis rasio efisiensi, kinerja Badan Pendapatan Daerah Kota 
Denpasar untuk pemungutan Pajak Bumi dan Bangunan Perdesaan dan Perkotaan tergolong sangat efisien karena menunjukkan rata-rata nilai rasio di bawah $60 \%$ yaitu sebesar 2,82\%. Persentase rasio semakin efisien pada tahun 2016 yaitu sebesar 0,09\%. Berdasarkan analisis rasio efektivitas, kinerja Badan Pendapatan Daerah Kota Denpasar untuk pemungutan Pajak Bumi dan Bangunan Perdesaan dan Perkotaan memperoleh kriteria sangat efektif karena menunjukkan rata-rata nilai rasio di atas $100 \%$ yaitu sebesar $105 \%$. Nilai rasio efektivitas yang ditunjukkan dari tahun 2013-2017 merupakan kinerja yang sangat baik karena pendapatan Pajak Bumi dan Bangunan Perdesaan dan Perkotaan sudah melebihi target yang telah ditetapkan.

Badan Pendapatan Daerah Kota Denpasar melalui seluruh Kepala Bidang dan Kepala Sub. Bidang telah berupaya meningkatkan penerimaan Pajak Bumi dan Bangunan Perdesaan dan Perkotaan baik dengan melakukan intensifikasi dan ekstensifikasi melalui beberapa kegiatan. Dengan adanya upaya-upaya yang telah dilakukan Badan Pendapatan Daerah Kota Denpasar dapat mengurangi kendala yang dihadapi dalam pemungutan Pajak Bumi dan Bangunan Perdesaan dan Perkotaan serta dapat meningkatkan penerimaan pendapatan Pajak Bumi dan Bangunan Perdesaan dan Perkotaan, sehingga nantinya akan meningkatkan pendapatan pajak daerah dan PAD di Kota Denpasar.

Berdasarkan simpulan di atas, maka saran yang dapat diberikan oleh peneliti adalah untuk penelitian selanjutnya dapat mengamati pajak daerah yang lainnya, dapat menggunakan metode Balanced Scorecard sebagai pengukuran kinerja, serta dapat menggunakan lokasi penelitian di daerah lainnya. Saran yang 
diberikan peneliti untuk Badan Pendapatan Daerah Kota Denpasar adalah Badan Pendapatan Daearah Kota Denpasar sebaiknya memperhatikan antara anggaran dan realisasi biaya yang dikeluarkan untuk memungut Pajak Bumi dan Bangunan Perdesaan dan Perkotaan; Badan Pendapatan Daerah Kota Denpasar juga harus memperhatikan antara target dan realisasi penerimaan Pajak Bumi dan Bangunan Perdesaan dan Perkotaan sehingga di masa mendatang kinerja Badan Pendapatan Daerah Kota Denpasar dapat meningkat dan menjadi lebih baik; serta Badan Pendapatan Daerah Kota Denpasar juga dapat melakukan kegiatan-kegiatan yang memancing minat masyarakat dalam membayar Pajak Bumi dan Bangunan Perdesaan dan Perkotaan sehingga akan meningkatkan penerimaan pendapat pajak daerah dan sekaligus akan meningkatkan PAD Kota Denpasar.

\section{REFERENSI}

Alwardat, Y. A., Benamraoui, A., \& Rieple, A. (2015). Value for Money and Audit Practice in the UK Public Sector, 217, 206-217. https://doi.org/10.1111/ijau.12037.

Anthony, R.N \& Govindarajan. (2007). Management Control System. McGraw Hill, New York.

Badan Pendapatan Daerah Kota Denpasar. (2017). Buku Data Mini. Denpasar: Badan Pendapatan Daerah Kota Denpasar.

Barnett, C., Barr, J., Christie, A., Duff, B., \& Hext, S. (2010). Measuring the Impact and Value for Money of Governance Programmes. Itad, (December), 1-37. https://doi.org/10.1016/0022-0248(94)00880-9.

Bastian, Indra. (2006). Akuntansi Sektor Publik: Suatu Pengantar. Jakarta: Erlangga.

Bawole, J. N., Ibrahim, M., Bawole, J. N., \& Ibrahim, M. (2016). Value-ForMoney Audit for Accountability and Performance Management in Local Government in Ghana Value-For-Money Audit for Accountability and 
Performance Management in, 692(May). https://doi.org/10.1080/01900692.2016.1142999.

Burger, P., \& Hawkesworth, I. (2011). How To Attain Value for Money: Comparing PPP and Traditional Infrastructure Public Procurement by. OECD Journal on Budgeting, 2011(1), 1-56. https://doi.org/10.1787/16812336.

Dewi, D. K. \& Suartana W. (2018). Penilaian Kinerja Berbasis Value for Money dan Sistem Online Penerimaan Pendapatan Asli Daerah Kabupaten Badung, $22,1281-1307$.

Dimitri, N. (2013). Article information :"Best value for money" in procurement, $13(2), 149-175$.

Direktorat Jenderal Pajak. (2012). Pajak Pusat dan Pajak Daerah. Jakarta: Indonesia.

Eze, N. M., \& Ibrahim, M. M. (2015). Value for Money Audit: A Veritable Tool for Expenditure Management, 6(3), 150-162. https://doi.org/10.5430/ijfr.v6n3p150.

Franzoni, S. (2013). Measuring corporate culture. Corporate Ownership and Control, $10(4 \quad$ D,CONT3), 308-316. https://doi.org/10.1111/j.14682370.2009.00274.x.

Halim, Abdul. (2008). Akuntansi Keuangan Daerah edisi ke-3. Jakarta: Salemba Empat.

Ismail, K., Takim, R., \& Nawawi, A. H. (2012). A public sector comparator (PSC) for value for money (VFM) assessment tools. Asian Social Science, 8(7), 192-201. https://doi.org/10.5539/ass.v8n7p192.

Jacobs, K. (1998). Value For Money Auditing In New Zealand: Competing For Control In The Public Sector, (April), 343-360.

Kadafi, L. (2014). Melalui Pendekatan Value For Money Pada Badan Lingkungan Hidup Kota Tanjung Pinang.

Koufteros, X., Verghese, A., \& Lucianetti, L. (2014). The effect of performance measurement systems on firm performance: A cross-sectional and a longitudinal study. Journal of Operations Management, 32(6), 313-336. https://doi.org/10.1016/j.jom.2014.06.003.

Laksmi, Sonia Wina G.A \& N.L. Supadmi. (2014). Efektivitas Pemungutan Pendapatan Asli Daerah dan Kontribusinya Pada Pendapatan Daerah, 
9(2):515-24.

Liando, H. S., Paul, D., Saerang, E., \& Elim, I. (2014). Analisis Kinerja Keuangan Pemerintah Kabupaten Kepulauan Sangihe Menggunakan Metode Value for Money, 2(3), 1686-1694.

Mahmudi. (2011). Akuntansi Sektor Publik. Yogyakarta: UII Press.

Marayasa, M. \& I. K. Jati. (2017). Penilaian Kinerja Berdasarkan Konsep Value For Money Untuk Penerimaan Pajak Hotel Dan Restoran, 20(1), 788-813.

Mardiasmo. (2002). Akuntansi Sektor Publik. Yogyakarta: Andi. . (2009). Akuntansi Sektor Publik. Yogyakarta: Andi. (2016). Perpajakan. Yogyakarta: Andi.

Peraturan Daerah Kota Denpasar Nomor 4 Tahun 2012 tentang Pajak Bumi dan Bangunan Perdesaan dan Perkotaan.

Purnomo, A., Putra, A \& Gusti, N., Wirawati, P. (2015). Penilaian Kinerja Berbasis Value for Money Atas Penerimaan Pendapatan Asli Daerah Kabupaten Tabanan. E-Jurnal Akuntansi Universitas Udayana, 11(1), 252268.

Purwiyanti, D. (2017). Analisis Kinerja Berbasis Konsep Value For Money Pada Kegiatan Fisik Pekerjaan Irigasi Donggala Kodi ( Study di Dinas Pekerjaan Umum Kota Palu ), 190-200.

Rahmad, H. (2015). Pengaruh Pengelolaan Keuangan Daerah dan Sistem Akuntansi Keuangan Daerah Terhadap Kierja Pemerintah Daerah, 859-867.

Rosca, V. (2013). A model for measuring value for money in professional sports, $X X(7), 77-86$.

Sambodo, Agus. (2015). Pajak dalam Entitas Bisnis. Jakarta: Salemba Empat.

Sangmi, M \& Tabassum, N. (2010). Analyzing Financial Performance of Commercial Banks in India: Application of CAMEL Model. Pakistan Journal Commercial Social Sciences.

Santandrea, M., Bailey, S., \& Giorgino, M. (2015). Value for money in UK healthcare public - private partnerships: A fragility perspective. https://doi.org/10.1177/0952076715618003.

Sari, Diana. (2013). Konsep Dasar Perpajakan. Bandung: PT Refika Adimata. 
Soomro, M. A., Soomro, S. A., Authority, N. H., \& Memon, A. H. (2016). Process And Limitations Of Value For Money Analysis Tests For Infrastructure Public Private Partnerships, (August).

Sudiarsa, K. (2011). Analisis Realisasi Program Badan Perencanaan Pembangunan Daerah ( Bappeda ) Kabupaten Buleleng.

Sugiyono. (2017). Metode Penelitian Pendidikan Pendekatan Kuantitaif, Kualitatif, dan R\&D. Metode Penelitian Pendidikan Pendekatan Kuantitaif, Kualitatif, Dan R\&D. https://doi.org/10.1016/S0084-3970(08)79262-4.

Suryantari, P. D., \& Ulupui, I. G. K. A. (2016). Kinerja Dinas Pariwisata Bali Berdasarkan Konsep Value for Money, 17(2), 1635-1666.

Taras, T. \& L. G. Sri Artini. (2017). Analisis Pendapatan Asli Daerah ( Pad ) Dalam Upaya Pelaksanaan Otonomi Daerah Di Kabupaten Badung Bali. EJurnal Manajemen Universitas Udayana, 6(5), 2360-2387.

Udhiyani, Ni Made Vitri, Made Ary Meitriana, A. Z. (2014). Value For Money Terhadap Phr Tahun 2008-2012, 4(1).

Undang-Undang Nomor 23 Tahun 2014 tentang Pemerintah Daerah

Undang-Undang Nomor 28 Tahun 2007 tentang Pajak.

Undang-Undang Nomor 28 Tahun 2009 tentang Pajak Daerah dan Retribusi Daerah.

Undang-Undang Nomor 33 Tahun 2004 tentang Perimbangan Keuangan Antara Pemerintah Pusat dan Pemerintah Daerah.

Waluyo. (2011). Perpajakan Indonesia. Jakarta: Salemba Empat.

Watermeyer, R., Africa, S., Africa, W., \& Environment, B. (2013). Value For Money In The Delivery Of Public, 1-15.

Wibisono, Arief. (2016). Pendapatan Kota Denpasar Terbesar dari PBB. Bali Tribune, 29 April 2016. http://balitribun.co.id/content/pendapatan-kotadenpasar-terbesar-dari-pbb.

Yeni, D. Y. \& P. Ery Setiawan. (2013). Evaluasi Kinerja Dinas Pendapatan Daerah Kota Denpasar Dalam Pemungutan Pajak Hotel, Restoran, Dan Hiburan Tahun 2008-2012, 4(1), 74-91. 